\title{
Legal Protection for Foreign Workers in Indonesia: Opportunities and Challenges
}

\author{
Dr. Harris Oemar
}

Lecturer in Management Study at the Postgraduate Program (S-2), Universitas Batam

\begin{abstract}
The impact of globalization and the current free market in the form of movement of investment, capital and labor between countries is unavoidable. Indonesia, as a member of the World Trade Organization (WTO), opens up opportunities for investment and foreign workers to run its business. The purpose of this research is to find out about legal protection for foreign workers in Indonesia as regulated by the 1945 Constitution and various other laws and regulations. This study uses a qualitative approach that is normative juridical, and the specification of the analysis of this research is carried out descriptively. The results show that the provisions regarding foreign workers in Indonesia still have many obstacles, especially in promoting investment, creating new regulatory challenges that may need to be responded to by policy makers in Indonesia quickly, and the right strategy is needed in the field of using foreign workers. although Law No. 11 of 2020 has been passed and optimizes the role of non-government organizations (NGOs) as assisting institutions for foreign workers to increase awareness of human rights in Indonesia
\end{abstract}

Keywords: Globalization, The 1945 Constitution, Foreign Workers, Indonesia, And Non-Government Organizations (Ngos).

\section{Introduction}

Trade expansion in the era of globalization is increasing, and the indicators are the increasing economic integration and the increasing contribution of trade to development. This is marked by the liberalization of tariffs and other trade barriers; foreign direct investment through trade and negotiations and investment agreements; technological innovation in the field of transportation and communication; international solidarity through supporting actions such as trade preferences; and the strategic use of policies, experiments and innovations as well as policies in the labor sector. According to UNCTAD (2008: vii), the benchmarks of increasing quantitative economic integration and the contribution of trade to development include increased competitiveness and increased productive capacity, adequate and modern infrastructure (physical and social), trade facilitation, human resource development, diversification, higher production and export value added, job creation, a healthy financial and investment climate, a culture of competition, technological advances, and many more. environmentally friendly and climate friendly production, consumption and trade patterns - will also be needed.

Referring to the description of the 1945 Constitution, it can be interpreted that the national economy is organized based on economic democracy with the principles of togetherness, justice, sustainability, environmental insight, independence, and guarantees that everyone has the right to work, to receive compensation and fair and proper treatment in relationships. work based on human rights (HAM). On the other hand, the impact of globalization and the current free market in the form of movement of investment, capital and labor between countries is unavoidable. As a member of the World Trade Organization (WTO), Indonesia opens up opportunities for investment and foreign workers to run their business and requires direct supervision by owners / investors. To anticipate this, it is necessary to have a complete set of laws and regulations that regulate the requirements and protection of foreign workers (Tenaga Kerja Asing - TKA). Basic aspects and forms of regulations aim to regulate and overcome (repressive) and avoid (preventive) legal problems related to the use of foreign workers (TKA) while still prioritizing Indonesian workers (Tenaga Kerja Lokal - TKI). Therefore, the government must be careful in determining the policy resulting 
from the entry of foreign workers to Indonesia in the form of statutory regulations that are in line with the constitution. According to Khoe (2013: 3), juridically in labor law the position of employers and workers is the same and equal. However, sociologically, in a certain condition, the position between workers or it can be said that workers and entrepreneurs are not equal and balanced. Because workers / laborers are often in a weak position, therefore in the world of employment, workers / laborers are the people who must be given protection of their rights (Khoe (2013: 3).

The existence of illegal foreign workers is one of the problems that occur in many countries in the world in the midst of the dynamics of the global economy that is increasingly open at this time (Jazuli, 2018: 90). According to Pottag (2018: 238), problems related to foreign workers working in Indonesia are increasing, and the legal impact of these problems is the increasing violation of various kinds of laws and regulations regarding immigration, where many foreigners are negligent or deliberately not. reporting in carrying out its obligations as referred to in Article 71 letter a of Law No. 6 of 2011 concerning immigration, namely the obligation of foreigners to provide all information regarding the identity of themselves and their families and to report any changes in civil status, citizenship, employment, guarantor, or change of address to the local immigration office.

Then, another impact is economically, the presence of foreign workers can close job opportunities for Indonesian citizens in obtaining strategic positions in a particular company (Pottag, 2018: 238).Another problem related to the presence of foreign workers in Indonesia is the perception of Indonesian people who tend to be inferior and often view foreign nationals (expatriates) as having superior knowledge and skills compared to local people (Warga Negara Indonesia - WNI). An inferior attitude, more permissive towards foreign citizens and even more aggravated by the 'abroad minded' attitude, is seen in society as consumers such as: foreign goods have a higher 'value' compared to goods produced domestically, graduates universities from abroad are considered more qualified than domestic university graduates. This is reflected in the large difference in wage levels between local workers and foreign workers even though they are at the same level of position. This phenomenon must immediately be minimized and strived to be eliminated because in fact local workers (TKL) and goods / services produced in the country are no less good when judged from the aspect of quality. Then, from the aspect of labor, the ability to compete with local workers has shown positive things, both in terms of education and skills when compared to foreign workers. Therefore, this optimistic attitude must be in line with efforts to improve the quality of the human resources (HR) of the Indonesian workforce with the aim that Indonesian workers become masters in their own country.

Based on these various descriptions, legal protection for foreign workers (TKA) in Indonesia is a critical issue in this research which includes statutory devices, legal protection for foreign workers (TKA) and the important role of non-government organizations (NGOs) for TKA. In this case, NGOs are a practical solution, namely NGOs to protect and assist foreign workers and local workers (TKL) through efforts to increase awareness of human rights in Indonesia.

\section{Methodology}

This study uses a qualitative approach that is normative juridical in nature, namely by analyzing problems through legal norms contained in statutory regulations in Indonesia: "law as it is written in the books", and based on the view that law is a norm. - positive norms contained in the statutory system related to the economic sector (Pinangkaan, 2015: 11). This research is also a doctrinal legal research which is a study by looking at how it should be according to the normative provisions and the specification of the analysis of this research is carried out in a descriptive manner, the description is the precise measurement and reporting of the characteristics of some population or phenomenon under study ((Babbie, 1986: 91). Then, the steps taken are through library research which examines (especially) secondary data in the form of: primary legal materials and secondary legal materials). Primary legal materials include the 1945 Constitution of the Republic of Indonesia, Law no. 11 of 2020 concerning Job Creation.

\section{Literature Review}

According to the World Bank (2000) in Bhorat \& Lundall (2004: 1), globalization is intended to instill the idea that the world through many nation-states has increased its interconnectedness at an extraordinary rate over the past two to three decades. The term globalization began to appear in literature from the 1980s 
which initially referred to files of economic transactions and economic growth and penetrated into other fields such as politics, culture, and their influence in various worlds of life which was marked by a revolution in information technology which had implications for removing boundaries. - state boundaries, such as the weakening of state authority, the emergence of a global governance system, politics (Banda, 2019: 3), the movement of goods, services, growing transnational capital, increasing homogenization of consumer tastes, consolidation and expansion of corporate power, a sharp increase in wealth and poverty, and the growing ideas of liberal democracy are everywhere (Guttal, 2007: 523).

According to Jaumotte \& Tytell (2007: 4-5). the effective global workforce has quadrupled over the past two decades, and this growing pool of the global workforce accessed by developed countries through a variety of channels, including imports of final goods, intermediate production offshoring, and immigration have contributed to increased labor compensation. real employment in developed countries by increasing productivity and output, while markets of developing countries also benefit from increases in real wages. Nonetheless, rapid technological changes have had a greater impact, particularly on workers in the unskilled sector, and going forward, it is important for countries to maximize the benefits of globalization of labor and technological change, while working to overcome the impact of distribution to improve functioning labor market; strengthening access to education and training; and ensuring an adequate social safety net so as to protect the impact of rapid technological changes (Jaumotte \& Tytell, 2007: 4-5) .Increasing quantitative economic integration and trade contribution to require economic growth based on the Millennium Development Goals (MDGs) and the Monterey Consensus on Financing for Development. The MDGs and the Monterey Consensus aim to reduce inequality and democratize trade and development progress within and across countries are essential attributes of a globalizing world to achieve human and social development including food security, energy security, rural development, universal access to essential services, gender equality, and poverty alleviation (UNCTAD, 2008: vii).

Bearing in mind that developing countries - such as Indonesia, usually have characteristics with a large number of workers and therefore have a comparative advantage in the labor-intensive sector to promote industry and adopt technology that is in line with the national development goals in Indonesia as mandated by the constitution, Article 33 paragraph ( 1), paragraph (2), paragraph (3) and paragraph (4) of the 1945 Constitution; and Article 28 D paragraph (2) of the 1945 Constitution.According to article 33 paragraph (1) of the 1945 Constitution states: "The economy is structured as a joint effort based on the principle of kinship.", And Article 33 paragraph (2) of the 1945 Constitution states: "Production branches which are important for the state and which control life. the people are controlled by the state. ". Then, Article 33 Paragraph (3) of the 1945 Constitution states: "The land and water and natural resources contained therein are controlled by the state and used for the greatest prosperity of the people". Furthermore, Article 33 paragraph (4) of the 1945 Constitution explains that: "The national economy is organized based on economic democracy with the principles of togetherness, efficiency with justice, sustainability, environmental insight, independence, and by maintaining a balance between progress and national economic unity". In this case, it can be interpreted that Article 33 of the 1945 Constitution is imperatively the basis for the development of economic law in Indonesia.

As a rule of law, Indonesia is a country that is obliged to uphold human rights. The 1945 Constitution of the Republic of Indonesia (UUD 1945) has mandated protection against violence or harassment, especially in the work environment. According to Article $28 \mathrm{D}$ paragraph (2) of the 1945 Constitution states that: "Everyone has the right to work and to receive fair and proper compensation and treatment in a work relationship". This verse shows that all people are equal and should not be treated arbitrarily in the work environment, including being victims of harassment. According to article $28 \mathrm{G}$ of the 1945 Constitution, it states that: "Everyone has the right to protect himself, family, honor, dignity and property under his control, and has the right to a sense of security and protection from the threat of fear to do or not do something which constitutes rights. Everyone has the right to be free from torture or treatment that degrading human dignity and has the right to obtain political asylum from other countries ".According to Article 28 I paragraphs (1) and (2) of the 1945 Constitution states: "The right to life, the right not to be tortured, the right to freedom of thought and conscience, the right to religion, the right not to be enslaved, the right to be recognized as a person before the law, and the right not to be prosecuted based on retroactive law is a human right that cannot be reduced under any circumstances. Everyone is free from discriminatory treatment on any basis 
and has the right to receive protection against such discriminatory treatment ". According to Masnun \& Wijayani, (2010: 99-100), basically the protection and rights provided by the Migrant Workers Convention only strengthen and complement other UN Human Rights Instruments that have been ratified by Indonesia on September 22, 2004 (Dewi 2018: 59) ..

Then, the objectives of the Migrant Workers Convention are as follows: (1) To create a minimum standard which States Parties to the Convention must apply to migrant workers and their families regardless of their migration status - whether documented or undocumented - (International Convention on the Protection of the Rights of All Migrant Workers and Members of Their Families, Preamble para 14); (2) The coverage of protection which covers all migrant workers according to the definition in Articles 1 and 2 of the Convention regardless of their migration status is a logical consequence of the main reason for the drafting of the Convention, namely that the most vulnerable to exploitation and human rights violations are those who fall into the category undocumented or irregular migrant workers; and (3) The protection provided for documented migrant workers that is included in the definition of Articles 1 and 2, including foreign professional workers, is only an additional guarantee / complements the rights of workers that have been stated in the work contract which is generally comprehensive. (Masnun \& Wijayani, 2010: 99-100)

\section{Results and Discussions}

\section{The set of laws and regulations on foreign workers (TKA)}

In order to support economic development in Indonesia, the government is currently trying to attract more interest from foreign investors by providing stimulus so that foreign investors invest in Indonesia. Various strategies are carried out by the government, such as implementing infrastructure development to simplifying licensing so that business players from abroad enter and invest in Indonesia. Geographically, Indonesia is in the form of an archipelago and has a wide area coverage and a very strategic location and has the potential for relatively high natural wealth, which is Indonesia's advantage in the international market. Therefore, infrastructure development must be carried out to facilitate access and mobility so that the government certainly needs a lot of foreign capital to ensure that all regions in Indonesia receive adequate and equitable development. Foreign investment is expected to be able to increase the number of exports, especially in the product sector.

Meanwhile, in the tourism sector, the rapid development of tourist destinations will attract foreign tourists to come, thereby increasing the country's foreign exchange earnings. In general, foreign investment in Indonesia is divided into several sectors, the development sector, tourism, mining, transportation, and products. The sector is determined according to the potential of each region. For example, Bali and Lombok can attract foreign investors in the tourism sector, building hotels and tourist attractions. In Sumatra and Kalimantan, oil palm can flourish so that foreign investment is needed in the oil palm plantation sector and foreign investors can build palm oil processing factories to advance the local economy. Apart from palm oil, Sumatra and Kalimantan with extraordinary wealth potential such as mining and natural resources (minerals, liquefied natural gas, coal, and petroleum) are potential to attract foreign investors so that they can invest their capital maximally by means of set up companies and factories. Likewise in various other regions in Indonesia.

Based on the geographic potential of Indonesia, efforts to attract foreign capital investment are expected to be directly proportional and become an opportunity in efforts to create job opportunities and absorb local labor (TKL). On the other hand, the challenges of the world of labor are faced with increasingly complex and tough conditions in addition to an increasing workforce. Then, Bappenas estimates that Indonesia's population will be 271 million in 2020 with a population growth rate of 1.9 percent and a fairly high increase in the workforce. as well as very fast population growth, an average of 1 percent each year which places Indonesia as the 4th most populous country in the world (Pigai, Factanews.id / 8/11/2019). Furthermore, there is a condition of uncertainty about the future of the Covid-19 pandemic which has an impact on socio-economic consequences, which affect consumption and investment behavior so that restrictions on social distance and mobility can make certain types of businesses unworkable, while encouraging others to grow (Zhenmin, 2020 : 7). This in turn could create new regulatory challenges that 
policymakers in Indonesia may need to respond to quickly, and requires a proper strategy in the area of using foreign workers (TKA).

Therefore, hiring foreign workers should be carried out through very strict mechanisms and procedures, especially by requiring companies or corporations that employ foreign workers to work in Indonesia by making plans for the use of foreign workers (RPTKA) as regulated in regulations and legislation. Various regulations and laws regarding the use of foreign workers in Indonesia before (http://ditjenpp.kemenkumham.go.id/.), And after the adoption of the Omnibus Law Cipta Kerja (OLCK) by the House of Representatives of the Republic of Indonesia (DPR RI) on October 5, 2020, and signed by the President of the Republic of Indonesia Joko Widodo on November 2, 2020 and promulgated in Law No. 11 of 2020 (Al Faqi, \& Moerti, 2020; Sandy, 2020) as follows:

Table 1: Legislations and Regulations on the Use of Foreign Workers in Indonesia Before and After Law No. 11 of 2020 concerning Job Creation

\begin{tabular}{|l|l|l|}
\hline \multirow{3}{*}{ No } & \multicolumn{2}{|l|}{ Laws and Regulations on the Use of Foreign Workers in Indonesia } \\
\cline { 2 - 3 } & Before Law No. 11 of 2020 concerning Job Creation & $\begin{array}{l}\text { After Law No.11 of } \\
2020 \text { concerning Job } \\
\text { Creation }\end{array}$ \\
\hline
\end{tabular}



Foreign Migrant Workers (TKWNAP):

Foreign Workers

A. Article 42 UUK No. 13 of 2003

In contrast to the Manpower Law which uses the term foreign labor for foreign citizens who hold visas with the intention of working in the territory of the Republic of Indonesia (NKRI), in Presidential Decree Number 75 of 1995 concerning the Use of Foreign Migrant Workers (TKWNAP), use the term foreign citizen migrant workers, namely workers of foreign nationals who have a limited residency visa or limited stay permit or permanent permit for the purpose of working (doing work) from within the territory of the Republic of Indonesia (Article 1 point 1). The term TKWNAP is considered inaccurate, because a foreign worker not only comes (as a migrant) from outside the territory of the Republic of Indonesia, but there is a possibility that a foreign worker is born and resides in Indonesia because of the immigration status of his parents (based on the principle of ius soli or ius sanguinis).

In principle, Presidential Decree Number 75 of 1995 concerning the use of foreign migrant workers is obliging to prioritize the use of Indonesian workers in the fields and types of work available unless there are fields and types of work available that are not or are not fully filled by Indonesian workers. then the use of foreign migrant workers is allowed up to a certain time limit (Article 2). This provision hopes that Indonesian workers will be able to adopt the skills of the foreign workers concerned and implement them themselves without having to involve foreign workers. Thus, the use of foreign workers is carried out selectively in order to optimize the utilization of Indonesian workers.

Law Number 13 of 2003 concerning Manpower (UUK):

Prior to the birth of Law Number 13 of 2003 concerning Manpower (UUK), the use of foreign workers in Indonesia was regulated in Law Number 3 of 1958 concerning the Placement of Foreign Workers (UUPTKA). In its journey, regulations regarding the use of foreign workers are no longer regulated in a separate law, but are already part of the compilation of the new Manpower Law. In the UUK, regulations on the use of foreign workers (TKA) are contained in Chapter VIII, Article 42 to Article 49. The regulation starts with the obligation of employers to use TKA to obtain written permits; has a plan for the use of the TKA which contains the reasons, type of position and period of time for using the TKA; the obligation to appoint Indonesian citizens to accompany foreign
In Law no. 11 of 2020 concerning Job

Creation, Article 42 of UUK No. 13 of 2003 is amended to:

(1) Every employer who employs foreign workers is obliged to have a plan for the use of foreign workers which is approved by the Central Government.

(2) Individual employers are prohibited from employing foreign workers.

(3) The provisions referred to in paragraph (1) do not apply to:

a. directors or commissioners with certain share ownership or shareholders in accordance with the provisions of laws and regulations;

b. diplomatic and consular staff at representative offices of foreign countries; or

c. foreign workers required by the Employer in the type of production activity that has stopped due to emergencies, vocations, start-ups, business visits, and research for a certain period of time.

(4) Foreign workers can be employed in Indonesia only in a working relationship for 
workers; to the obligation to return the foreign worker to the country of origin after the end of the employment relationship.

UUK emphasizes that every entrepreneur is prohibited from employing foreigners without written permission from the Minister. The definition of foreign workers is also narrowed, namely foreign nationals holding visas with the intention of working in Indonesian territory. In this provision, it is reaffirmed that every employer who employs foreign workers is required to have written permission from the Minister or an appointed official. To provide wider employment opportunities for Indonesian workers (TKI), the government limits the use of foreign workers and carries out supervision. In this context, the Government has issued a number of legal instruments ranging from licensing, health protection guarantees to supervision. A number of regulations are ordered by the UUK, including: 1) Ministerial Decree concerning Certain Positions and Certain Times (Article 42 paragraph (5)); 2) Ministerial Decree on Procedures for Ratification of Plans for the Use of Foreign Workers (Article 43 paragraph (4)); 3) Ministerial Decree on Position and Competency Standards (Article 44 paragraph (2)); 4) Ministerial Decree on Certain Positions Prohibited from Assigning Foreign Workers (Article 46 paragraph (2)); 5) Ministerial Decree on Certain Offices in Educational Institutions that are Exempted from Compensation Payments (Article 47 paragraph (3)); 6) Government Regulation on the Amount of Compensation and Its Use (Article 47 paragraph 4); 7) Presidential Decree on the Use of Foreign Workers and the Implementation of Education and Training for Companion Workers (Article 49).

Since the UUK was promulgated on March 25, 2003, several implementing regulations have been issued [1], including: 1) Decree of the Minister of Manpower and Transmigration Number 223 / MEN / 2003 concerning Positions in Educational Institutions that are Exempted from Obligations. Paying Compensation; 2) Decree of the Minister of Manpower and Transmigration Number 67 / MEN / IV / 2004 concerning the Implementation of the JAMSOSTEK Program for Foreign Workers; 3) Ministerial Regulation Number PER.02 / MEN / III / 2008 concerning Procedures for Employing Foreign Workers.

Furthermore, it is explained that in order to meet the needs of the national labor market, especially in filling the void of expertise and competence in certain fields that cannot be covered by Indonesian workers, foreign workers can be employed in Indonesia as long as they are in a work relationship for a certain position and for a certain time. Employment of foreign workers can be done by any party in accordance with the provisions except for the individual employer. Every employer who employs foreign workers must have written permission from the minister or appointed official, except a certain position and for a certain time and have the competence according to the position to be occupied.

(5) Foreign workers are prohibited from occupying positions in charge of personnel.

(6) Provisions regarding certain positions and certain times as referred to in paragraph (4) and paragraph (5) shall be regulated by a Government Regulation

Article 42 paragraph (6) which regulates foreign workers whose working period has expired and can be replaced with other foreign workers, is amended. Regulations regarding the expiring working period of foreign workers will be re-regulated by a Government Regulation.

\section{B. Article 43 UUK No. 13 Year 2003:}

In the Job Creation Law, Article 43 is deleted.

More about this source textSource text required for additional translation information

\section{Article 44 UUK No. 13 of 2003:}

(1) Employers of foreign workers are required to comply with the provisions concerning positions and the applicable competency 
for representatives of foreign countries who employ foreign workers as diplomatic and consular employees. Provisions regarding certain positions and a certain time for foreign workers are stipulated by a Ministerial Decree, namely Ministerial Decree Number: KEP-173 / MEN / 2000 concerning the Period of Permits to Employ Foreign Migrant Workers.

Any application / plan for the use of foreign workers in Indonesia must be limited both in the number and in the fields that can be occupied by foreign workers. It is intended that the presence of foreign workers in Indonesia is not considered a serious threat to Indonesian workers, instead their presence is a trigger for Indonesian workers to be more professional and to always increase their ability to compete both among Indonesian workers and with the foreign workers. Therefore, the UUK limits the positions that can be held by foreign workers. Foreign workers are prohibited from holding positions in charge of personnel and / or certain positions which are further regulated by the Decree of the Minister of Manpower and Transmigration Number 223 of 2003 concerning Positions in Educational Institutions that are Exempted from the Obligation to Pay Compensation.

The positions that are prohibited (closed list) must be considered by the employer before applying for the use of foreign workers. In addition to obeying the provisions concerning positions, they must also pay attention to the applicable competency standards. Provisions regarding positions and competency standards are delegated to a Ministerial Decree. However, in practice, this delegative and attributive authority has not used the rules according to the UUK. The presence of foreign workers can be said to be one of the foreign exchange carriers for a country where there is a compensation payment for every foreign worker employed. The payment of this compensation is exempted from employers of foreign workers who are government agencies, representatives of foreign countries, international agencies, social institutions, religious institutions, and certain positions in educational institutions [2]. The amount of compensation funds for Indonesian workers abroad is US $\$ 15$, while the compensation for foreign workers in Indonesia is US \$ 100 [3]. In the context of implementing the Transfer of Knowledge from foreign workers to Indonesian workers, employers are obliged to provide education and training for accompanying workers (Article 49 of the UUK). Regarding this matter, it is regulated by a Presidential Decree which has yet to be stipulated.

Ministerial Regulation Number PER.02 / MEN / III / 2008 concerning Procedures for the Use of Foreign Workers:

This Ministerial Regulation is laid out in the context of implementing Article 42 paragraph (1) of the UUK. With the issuance of Ministerial Regulation Number PER.02 / MEN / III / standards.

(2) Provisions regarding positions and competency standards as referred to in paragraph (1) shall be regulated by a Ministerial Decree. Article 44 is deleted. In the Job Creation Law, the article on the provision that foreign workers are obliged to comply with the provisions regarding positions as stated in the Ministerial Decree is deleted

In Law no. 11 of 2020 concerning Job Creation, Article 44 of UUK No. 13 of 2003 is deleted.

\section{Article 45 UUK No. 13 of 2003:}

(1) An employer of foreign workers must:

a. appointing Indonesian citizen workers as counterpart workers for foreign workers who are employed to transfer technology and transfer skills from foreign workers; and

b. carry out work education and training for Indonesian workers as referred to in letter a in accordance with the qualifications

positions occupied by foreign workers.

(2) The provisions referred to in paragraph (1) do not apply to foreign workers who hold positions of directors and / or 
2008 concerning Procedures for the Use of Foreign Workers, several previous regulations were related to the implementation of Article 42 paragraph (1) of this Law, namely: Decree of the Minister of Manpower and Transmigration Number KEP.228 / MEN / 2003 concerning Procedures for Ratification of Plans for the Use of Foreign Workers; Decree of the Minister of Manpower and Transmigration Number KEP.20 / MEN / III / 2004 concerning Procedures for Obtaining Permits to Employ Foreign Workers; Decree of the Minister of Manpower and Transmigration Number KEP.21 / MEN / III / 2004 concerning the Use of Foreign Workers as Singing Guides / Karaoke; Regulation of the Minister of Manpower and Transmigration Number PER.07 / MEN / III / 2006 concerning Simplification of Procedures for Obtaining Permits to Employ Foreign Workers (IMTA); Regulation of the Minister of Manpower and Transmigration Number PER.15 / MEN / IV / 2006 concerning Amendments to the Regulation of the Minister of Manpower and Transmigration Number PER.07 / MEN / III / 2006 concerning Simplification of Procedures for Obtaining Permits to Employ Foreign Workers (IMTA); Regulation of the Minister of Manpower and Transmigration Number PER.34 / MEN / III / 2006 concerning Provisions for Granting Permits to Employ Foreign Workers (IMTA) to Entrepreneurs Who Hire Foreign Workers in the Position of Directors or Commissioners; revoked and declared invalid (Article 44).

1). Procedures for Requesting the Ratification of RPTKA - In addition to having a permit to employ foreign workers, previously an employer must have a Foreign Worker Utilization Plan (RPTKA) which is endorsed by the Minister or an appointed official. Article 3 states that "an employer who will employ a foreign worker must have an RPTKA" which is used as the basis for obtaining a permit to employ foreign workers (IMTA). To obtain RPTKA ratification, the employer of the TKA must submit a written application accompanied by the reasons for using the TKA by attaching: a completed RPTKA form; a business permit from the competent agency; a certificate of establishment as a legal entity that has been approved by the competent official; domicile statement companies from the local regional government; company organizational structure chart; letter of appointment of TKI as assistant to the employed TKA; copy of proof of compulsory employment report which is still valid based on Law Number 7 of 1981 concerning Obligatory Reporting of Employment in companies; and recommendations for positions to be occupied by foreign workers from certain agencies if necessary. RPTKA form as referred to in letter a contains: Identity of the TKA employer; Position and / or position of foreign workers in the organizational chart structure of the company concerned; Amount of foreign workers' wages to be paid; Number of TKA TKA work location; The term of use of foreign workers, Appointment of Indonesian citizens to assist the employed TKA [4]; and Planned education and training programs for Indonesian workers. commissioners.

In Law no. 11 of 2020 concerning Job Creation, Article 45 of UUK No. 13 of 2003 is amended to:

(1) An employer of foreign workers must:

a. appointing Indonesian citizen workers as counterpart workers for foreign workers who are employed to transfer technology and transfer skills from foreign workers;

b. carry out work education and training for Indonesian workers as referred to in letter a in accordance with the qualifications of positions occupied by foreign workers; and

c. repatriate foreign workers to their home countries after their employment relationship ends.

(2) The provisions referred to in paragraph (1) letter a and letter b do not apply to foreign workers who occupy certain positions.

In Law no. 11 of 2020 concerning Job Creation, Article 45 of UUK No. 13 of 2003 plus letter $\mathrm{c}$ regarding the return of foreign workers to the country of origin after the employment relationship ends.

E. Article 46 UUK No. 13 of 2003:

(1) Foreign workers are 
2). Ratification of RPTKA - In the event that the results of the feasibility assessment of the RPTKA application are in accordance with the established procedures, the Director General or the Director must issue a decision to ratify the RPTKA. Issuance of decisions on the ratification of RPTKA is carried out by the Director General for applications for the use of 50 (fifty) foreign workers or more; as well as the Director for applications for the use of TKA of less than 50 (fifty) people. The decision to ratify the RPTKA contains: Reasons for the use of TKA; Position and / or position of TKA in the organizational structure of the company concerned; Amount of TKA wages; Number of TKA; Location of work of TKA; Period for using TKA; Number of TKI appointed to assist TKA and the number of Indonesian labor migrants employed.

3). Changes to RPTKA - Employers of TKA can apply for changes to RPTKA before the end of the RPTKA period. The RPTKA changes include: a. addition, reduction of positions and the number of foreign workers; b. change of position; and / or c. change of work location.

4). Foreign Workers Requirements - Foreign Workers who are employed by the employer must meet the following requirements: having education and / or work experience of at least 5 (five) years in accordance with the position they will occupy; willing to make a statement to transfer their expertise to Indonesian citizens, especially Indonesian Workers (TKI) companions; and can communicate in Indonesian.

5). Permits - Permits to Use Foreign Workers (IMTA) are given by the Director of Procurement and Employment of the Ministry of Manpower and Transmigration to foreign workers employers [6], by first submitting an application to obtain a visa recommendation (TA-01) by attaching ( Article 23): Copy of Decree of Ratification of RPTKA; Copy of passport of TKA to be employed; Curriculum vitae of TKA to be employed; Copy of diploma and / or description of work experience of TKA to be employed; Copy of letter of appointment of counterpart workers; and 1 (one) sheet of color photographs measuring $4 \times 6 \mathrm{~cm}$.

In the event that the Directorate General of Immigration has granted a visa application to be able to work on behalf of the foreign worker concerned and issues a notification letter regarding approval for granting visas, the TKA employer submits an IMTA application by attaching (Article 24): a copy of the draft work agreement; proof of payment of compensation for the use of TKA through a Bank appointed by the Minister; copy of the insurance policy; copy of notification letter regarding approval for granting visas; and 2 (two) sheets of $4 \times 6$ size color photographs [7].

6). IMTA Extension - Regarding the extension of the Permit to prohibited from holding a position in charge of personnel and / or certain positions.

(2) Certain positions as referred to in paragraph (1) shall be regulated by a Ministerial Decree.

In Law no. 11 of 2020 concerning Job Creation, Article 46 of UUK No. 13 of 2003 is deleted. The article that regulates provisions for foreign workers who are prohibited from being hired for certain personnel or positions already exists in Article 42 of Law no. 11 of 2020 concerning Job Creation ...

\section{F. Article 47 UUK No. 13 of 2003:}

(1) An employer is obliged to pay compensation for every foreign worker he employs.

(2) The obligation to pay compensation as referred to in paragraph (1) does not apply to government agencies, representatives of foreign countries, international agencies, social institutions, religious institutions, and certain positions in educational institutions.

(3) Provisions regarding certain positions in educational institutions as referred to in paragraph (2) shall be regulated by a 
Employ Foreign Workers (IMTA) regulated in Article 27 and Article 28. IMTA can be extended for a maximum of 1 (one) year, if the IMTA validity period has not ended. Therefore, the application for an extension of the IMTA is no later than 30 (thirty) working days before the expiration of the IMTA validity period. Applications for IMTA extension are made by filling out the IMTA extension form by attaching: Copy of valid IMTA; Proof of payment of compensation funds for the use of foreign workers through the Bank appointed by the Minister; Copy of insurance policy; Training for assisting TKI; Copy of valid RPTKA decisions; and 2 (two) $4 \times 6 \mathrm{~cm}$ color photographs. Extension of IMTA is issued by: Director for TKA whose work location is more than 1 (one) provincial area; Governor or official responsible for manpower affairs in the province for TKA whose work location cross regencies / municipalities in 1 (one) province; regents / mayors or officials responsible for manpower affairs in regencies / cities for foreign workers whose work locations are within 1 (one) regency / city;

7). IMTA for Emergency Work - Work of an emergency nature or jobs that if not handled directly result in fatal losses to the general public and the period is not more than 30 (thirty) days, in which the type of urgent work is determined by the government agency in charge of the business sector concerned. This urgent application for IMTA is submitted to the Director by attaching: Recommendations from authorized government agencies; Copy of insurance policy; Photocopy of the relevant TKA's passport; 3 (three) copies of TKA's size 4 x $6 \mathrm{~cm}$; Proof of payment of compensation for the use of foreign workers through a bank appointed by the Minister; and Proof of a valid immigration permit.

8). IMTA for Special Economic Zones - To obtain IMTA for foreign workers working in special economic zones, employers of foreign workers must submit an application in writing to the appointed official in special economic zones. The procedure for obtaining an IMTA in special economic zones follows the provisions in point 5 (five).

\section{9). IMTA For Permanent Stay Permit Cardholders (KITAP) -} Employers who will employ foreign workers holding permanent residency permits are required to submit an application to the Director by attaching: Copy of valid RPTKA; Copy of valid permanent residence permit; Curriculum vitae of TKA to be employed Copy of diploma or work experience; Proof of payment of compensation funds for the use of foreign workers through a Bank appointed by the Minister; Copy of insurance policy; and 3 (three) pieces of color photographs measuring $4 \times 6 \mathrm{~cm}$.

10). IMTA for Singing / Karaoke Guide - Employers who will
Ministerial Decree.

(4) Provisions regarding the amount of compensation and its use are regulated by a Government Regulation.

In Law no. 11 of 2020 concerning Job Creation, Article 47 of UUK No. 13 of 2003 is amended to:

(1) An employer is obliged to pay compensation for every foreign worker he employs.

(2) The obligation to pay compensation as referred to in paragraph (1) does not apply to government agencies, representatives of foreign countries, international agencies, social institutions, religious institutions, and certain positions in educational institutions.

(3) Provisions regarding the amount and use of compensation as referred to in paragraph (1) shall be regulated in accordance with statutory provisions.

In Law no. 11 of 2020 concerning Job Creation, abolishes provisions for payment of compensation in educational institutions for certain positions in educational institutions regulated in a ministerial decree

In Law no. 11 of 2020 concerning Job Creation, Article 47 paragraph (3) of the Law No. 13 of 2003 is 
employ foreign workers as singing / karaoke guides are required to have written permission from the Director. The period of using a foreign worker as a singer / karaoke guide is given a maximum of 6 (six) months and cannot be extended. To obtain permission from employers, foreign workers must submit an application for IMTA by attaching: Copy of permit for business premises that have karaoke facilities; RPTKA which has been approved by the director; Proof of payment of compensation for the use of foreign workers through a bank appointed by the Minister; Copy of insurance policy; and the work agreement of the foreign worker with the employer.

11). Transfer of Status - Employers of foreign workers in government agencies or government agencies or international agencies that will transfer their foreign workers to government agencies or government agencies or other international agencies must submit a request for a recommendation for status transfer to the Director. Recommendations are submitted to the Director General of Immigration for changes to KITAS / KITAP which are used as the basis for changing the IMTA or issuing new IMTA.

12). Change of Employer Name - In the event that an TKA employer changes its name, the employer must submit an application for changing the RPTKA to the Director of Manpower Supply and Use of the Ministry of Manpower and Transmigration. After the RPTKA is approved, the Director of Provision and use of the Ministry of Manpower and Transmigration issues a recommendation to the Director General of Immigration to change the KITAS / KITAP as the basis for changing the IMTA, by first submitting an application by attaching: Copy of valid RPTKA; Copy of valid KITAS / KITAP ; Copy of valid IMTA; Copy of proof of change in company name that has been legalized by the competent authority.

13). Change of work location - In the event that an employer changes the work location of the TKA, the employer is obliged to submit an application for a change in the work location of the TKA to the Director of the Supply and Use of Manpower of the Ministry of Manpower and Transmigration by attaching a copy of the valid RPTKA and IMTA.

14). Reporting - Employers of foreign workers are required to report the use of foreign workers and foreign workers in the company every 6 (six) months to the Director or Governor or Regent / Mayor with a copy to the Director General. The Director or Governor or Regent / Mayor reports the IMTA issued periodically every 3 (three) months to the Minister with a copy to the Director General. deleted.

G. Article 48 UUK No. 13 of 2003:

Employers who employ foreign workers are obliged to return the foreign workers to their country of origin after their employment relationship ends.

In Law no. 11 of 2020 concerning Job Creation, Article 48 of UUK No. 13 of 2003 is deleted. The provisions in Article 48 of Law no. 13/2003 combined with article 45 in Law no. 11 of 2020 concerning Job Creation.

\section{H. Article 49 UUK No. 13 of 2003:}

Provisions regarding the use of foreign workers and the implementation of education and training for companion workers are regulated by a Presidential Decree.

In Law no. 11 of 2020 concerning Job Creation, Article 49 of UUK No. 13 of 2003 is amended to:

Further provisions regarding the use of foreign workers 432 are regulated in a Government Regulation. Article 49 underwent changes regarding the provisions for the use of foreign workers, which were originally regulated by a Presidential Decree into a Government Regulation 
15). Supervision - Supervision of employers who employ foreign workers is carried out by employees of labor inspectors in accordance with laws and regulations

16). Revocation of Permits - In the event that an employer employs foreign workers not in accordance with the IMTA, the Director or Governor or Regent / Mayor has the authority to revoke the IMTA.

Source: Compiled from various sources

Based on table 1 above, it can be explained that prior to the enactment of the Omnibus Job Creation Law (OLCK) it became Law No. 11 of 2020 concerning Job Creation, that there are several laws and regulations that regulate the use of foreign workers (TKA) in Indonesia, such as Presidential Decree Number 75 of 1995 concerning the Use of Foreign Migrant Workers (TKWNAP), Law Number 13 Year 2003 concerning Manpower (Undang-Undang Ketenagakerjaan - UUK), and Ministerial Regulation Number PER.02 / MEN / III / 2008 concerning Procedures for the Use of Foreign Workers. Then, in terms of the authority to issue permits for the use of foreign workers at the Ministry of Manpower, this is done through the ratification of the Plan for the Use of Foreign Workers and the issuance of a Notification on the Use of Foreign Workers.

The use of Foreign Workers is regulated by Presidential Regulation Number 20 of 2018 concerning the Use of Foreign Workers, and the implementing regulations are regulated by Regulation of the Minister of Manpower Number 10 of 2018 concerning Procedures for the Use of Foreign Workers. Article 4 of the Minister of Manpower Regulation Number 10 of 2018 mandates that every employer of Foreign Workers (TKA) who employs Foreign Workers is obliged to include Foreign Workers in the insurance program at an insurance company with an Indonesian legal entity who works for less than 6 (six) months. , and its implementation is regulated by a Decree of the Director General. The issuance of Decree of the Director General Number 3/7009 / HK.08 / VIII / 2019 concerning the Implementation of the Insurance Program for Foreign Workers Who Work for Less than Six Months is an integral part of the procedures for the use of Foreign Workers in Indonesian territory.

However, the provisions regarding foreign workers (TKA) in Indonesia still have many obstacles, especially in promoting investment. This is because a number of regulations that complement the smooth use of foreign workers are not yet ready, so to fill the legal vacuum with the issuance of the necessary regulations, the old regulations are still in effect. In the event that the placement of foreign workers can be carried out after the submission of the plan for the use of foreign workers (RPTKA) is approved by the Ministry of Manpower and Transmigration by issuing a permit to use foreign workers to work in Indonesia, they must have a limited stay permit (KITAS) in advance and must have a visa to work in Indonesia on behalf of the foreign worker concerned to be issued a permit by the Directorate General of Immigration, Ministry of Law and Human Rights (http://ditjenpp.kemenkumham.go.id/). With the enactment of the Job Creation Law, foreign workers only need RPTKA because they no longer need written permission from the minister or appointed official, and permits to enter TKA are simplified. This is regulated in Law No. 11/2020 concerning Job Creation Article 42 (1), "Every employer who employs foreign workers is required to have a foreign workforce utilization plan (RPTK) which is legalized by the Central Government". According to Law No. 11 of 2020 concerning Job Creation article 1 (5), the Central Government is the President of the Republic of Indonesia who holds the governmental power of the Republic of Indonesia assisted by the Vice President and ministers as referred to in the 1945 Constitution of the Republic of Indonesia.

\section{Legal protection for foreign workers (TKA)}

Trade liberalization is a condition in which companies and individuals are free to carry out economic activities in trading goods or services beyond the borders of their country, including being free to establish companies in other countries and for individuals to have the freedom to be able to work in other countries (Zamroni, 2003: 180 ) ,. According to experts in Khulaidah (2019: 30), in general, trade liberalization includes reducing and simplifying and even eliminating the structure of tariffs and various obstacles on a 
large scale. This step drastically resulted in the opening of the economic system in a more intensive trade relationship between countries, and some of the advantages of international trade liberalization for developing countries according to the theory of endogenous growth, including: trade liberalization would allow developing countries to absorb technology faster, more smoothly., research and development of knowledge will flow more smoothly and swiftly into developing countries (Khulaidah, 2019: 30).

Trade liberalization has direct implications for the development of the national economy, requires the use of foreign workers, and its aim is to meet the needs of professional workers in the context of transferring knowledge and increasing foreign investment. Economic growth is marked by opening the tap for investment with implications for the entry of foreign workers in Indonesia. The basic philosophy of using foreign workers in Indonesia is that they are needed in 2 (two) things, namely those (TKA) who bring capital (as investors) and / or bring skills in the context of transfer of knowledge or transfer of know-how (Hastuti et.al. ., 2005) to TKI, as well as expansion of job opportunities (Miru, 2008: 35). Therefore, employers of foreign workers are obliged to appoint Indonesian citizen workers as counterpart workers for foreign workers (TKA) who are employed for the purpose of transferring technology and transfer of expertise from foreign workers. In addition, employers of foreign workers are obliged to carry out education and training and every user of foreign labor (sponsor) is obliged to carry out a program of replacing foreign workers with Indonesian workers.

As a rule of law (rechtstaat), of course, it is one of the obligations for the Indonesian state to provide legal certainty for foreign workers working in Indonesia, and the need for foreign workers in Indonesia does not rule out that more and more foreign workers are in Indonesia so legal certainty is needed (Pottag, 2018: 238). In the context of legal protection for TKA and TKL workers, it is to provide guarantees related to basic rights of workers / labor, equal opportunity and non-discriminatory treatment on any basis to realize the welfare of workers / laborers and their families in accordance with the constitution. This can be carried out while still paying attention to the development of the progress of the business world.

Thus, the government has established new regulations regarding the use of foreign workers in Indonesia, namely by ratifying Presidential Regulation Number 20 of 2018 concerning the Use of Foreign Workers which reaps the pros and cons of various parties (Fitriah, 2019 ). One of the conventions that have completely protected the rights of migrant workers, namely the International Convention on the Protection of the Rights of All Migrant Workers and Members of Their Families, 1990. This protection is not only based on international law, but there needs to be a legal rule. national standards that adjust legal protection standards according to international standards in order to truly protect citizens of countries of sending migrant workers and receiving countries so that the objectives of this convention are achieved (Dewi, 2018: 59). In this regard, Indonesia has ratified the convention through Law no. 6 of 2012 concerning the Ratification of the International Convention On The Protection Of The Rights Of All Migrant Workers And Members Of Their Families, and it is hoped that later each country participating in the convention can pay attention to all provisions related to standards and principles contained in all human rights instruments and related instruments ( ILO core standards (Dewi, 2018: 59).

Therefore, foreign investment in Indonesia is fully aimed at enhancing the investment ecosystem and accelerating national strategic projects aimed at improving the welfare of the Indonesian people in order to fulfill citizens' rights to work and a decent living for humanity amid increasingly competitive competition and the demands of economic globalization. This has become the government's strategic agenda as stipulated in the preamble to Law No. 11 of 2020 concerning Job Creation as follows:

a. In order to realize the objectives of establishing the Indonesian State Government and realizing a prosperous, just, and prosperous Indonesian society based on Pancasila and the 1945 Constitution of the Republic of Indonesia, the State needs to make various efforts to fulfill citizens' rights to work and a decent life for humanity through work copyright;

b. Job creation is expected to be able to absorb the widest possible Indonesian workforce in the midst of increasingly competitive competition and the demands of economic globalization; that the work creation is expected to be able to absorb Indonesian workers as widely as possible in the midst of increasingly competitive competition and the demands of economic globalization; 
c. To support work creation, it is necessary to adjust various regulatory aspects relating to the convenience, protection and empowerment of cooperatives and micro, small and medium enterprises, enhancing the investment ecosystem, and accelerating national strategic projects, including improving the protection and welfare of workers;

d. Regulations relating to the convenience, protection and empowerment of cooperatives and micro, small and medium enterprises, enhancing the investment ecosystem, and accelerating national strategic projects, including improving the protection and welfare of workers scattered in various sector laws are currently unable to meet the needs law to accelerate work copyright so that changes need to be made;

e. Efforts to change regulations relating to the convenience, protection and empowerment of cooperatives and micro, small and medium enterprises, enhancing the investment ecosystem, and accelerating national strategic projects, including improving the protection and welfare of workers are carried out through changes to sector laws that have not supported the realization of synchronization in guarantee the acceleration of work copyrights, so that a legal breakthrough is needed that can comprehensively resolve various problems in several laws into one Law.

In terms of the entry of foreign workers (TKA), Indonesia faces considerable challenges including the large number of unemployed people, and the limited number of superior seeds for the workforce who have not been able to meet the needs of the employment sectors. Foreign workers who came to Indonesia occurred in various fields, such as education, construction, managers, to labor, and in various other fields of work. The number of foreign workers in Indonesia in 2020 reached 98,902 people, consisting of: foreign workers from China ranked first, namely 35,781 people. or the equivalent of $36.17 \%$., Japan 12,823 people, South Korea 9,097, India 7,356 people, Malaysia 4,816 people, Philippines 4,536 people, United States 2,596 people, Australia 2,540 people, England 2,176 people, Singapore 1,994 people and, 15,187 from other countries (Waseso, 2020).

Based on the 2009 National Survey Report on Foreign Workers in Indonesia by Bank Indonesia (2010: vii), it was found that the majority of respondents (44.4\%) gave a "moderate" predicate to legal protection in Indonesia followed by a group of respondents who gave a "good" predicate and "Very good" amounted to $35.3 \%$, and there were quite a lot of respondents (20.3\%) who gave the predicate "bad" or "very bad" which of course needs to be the attention of regulators in Indonesia. Therefore, legal protection for foreign workers is an opportunity and a challenge for all stakeholders such as the government, legislature, entrepreneurs (local / foreign), workers, academics, law enforcers, legal practitioners, other communities and especially the role of the community as Preventive institutions for foreign workers in Indonesia.

With the number of TKA and it is likely that this will continue to increase as after the enactment of Law No.11 of 2020 concerning Job Creation, the issues are related to. The participation of non-governmental organizations (NGOs) in development can be carried out in various ways according to their respective capabilities, for example issuing thoughts and opinions as juridical legitimacy for independence to express their opinions as regulated in the Constitution of the Republic of Indonesia, namely Article 28 of the 1945 Constitution after amendments which constitute the spirit of the people's sovereignty as citizens. This commitment is stated in article 123 paragraph (2) of Law No.39 of 1999 on Human Rights which states that: "Everyone is free to have, issue and disseminate opinions according to their conscience, orally and / or in writing through printed media, or electronically with due observance of religious values, decency, order, public interest and the integrity of the nation ".

\section{The role of non-government organizations (NGOs) for foreign workers}

The characteristics of foreign workers as migrant workers have determined Indonesia's development strategy related to the labor market and industrial relations. However, in several studies it has been proven that foreign workers have positive and negative impacts. According to Scientific Rev (https://ilmugeografi.com/2020), intense competition in the field of human resources (HR) due to globalization and free trade and the free economy has become opportunities and challenges for foreign workers in Indonesia related to the positive and negative impacts as follows:

Table 2: Positive and Negative Impacts of Foreign Workers in Indonesia 


\begin{tabular}{|c|c|c|}
\hline No & Positive Impacts & Negative Impacts \\
\hline 1 & $\begin{array}{l}\text { The entry of new knowledge and technology in a field of } \\
\text { work - With the presence of foreign workers, we will get new } \\
\text { knowledge in a field of work. We can get this new knowledge } \\
\text { from foreign workers who may be commonly practiced in } \\
\text { their home countries. With this new knowledge, it will } \\
\text { increase innovation in Indonesia. Not only new science, but } \\
\text { also new technology. Foreign workers bring technology used } \\
\text { from their home countries to be applied in Indonesia. This } \\
\text { will be very beneficial if foreign workers come from } \\
\text { developed countries in their fields. }\end{array}$ & $\begin{array}{l}\text { 1. Narrowing local workforce } \\
\text { employment opportunities - } \\
\text { The most pronounced negative } \\
\text { impact of the entry of foreign } \\
\text { workers is the narrowing of jobs } \\
\text { in the country. This is because } \\
\text { the number of workers will } \\
\text { increase. If it is not balanced } \\
\text { with an increase in domestic } \\
\text { business, employment } \\
\text { opportunities will become } \\
\text { increasingly narrow. }\end{array}$ \\
\hline 2 & $\begin{array}{l}\text { Development of an area becomes faster - The development } \\
\text { of a field of work is strongly supported by qualified and } \\
\text { expert human resources. The use of expatriates who are } \\
\text { experienced in a particular field can be a good means of } \\
\text { development in a field of work. And this good experience can } \\
\text { be passed on to local Indonesian people }\end{array}$ & $\begin{array}{l}\text { 2. Become a threat to local } \\
\text { workers who do not have } \\
\text { more skills - The arrival of } \\
\text { foreign workers to Indonesia } \\
\text { poses a separate threat to local } \\
\text { workers, especially those } \\
\text { without skills at all. If they are } \\
\text { not honed, local workers will } \\
\text { not be able to compete with } \\
\text { foreign workers. }\end{array}$ \\
\hline 3 & $\begin{array}{l}\text { Adoption of new technology is fast - Technology adoption } \\
\text { will be easy if there are personnel who are experts in their } \\
\text { fields. Technology from developed countries will be easy to } \\
\text { do if it is supported by someone who is experienced, } \\
\text { especially from the country of origin of the technology }\end{array}$ & \multirow[t]{3}{*}{$\begin{array}{l}\text { 3. Creating unemployment } \\
\text { opportunities - The presence of } \\
\text { foreign workers if not balanced } \\
\text { with additional employment } \\
\text { opportunities will only cause a } \\
\text { lot of unemployment. As a } \\
\text { solution, additional jobs must } \\
\text { also be done. }\end{array}$} \\
\hline 4 & $\begin{array}{l}\text { An increase in investment in Indonesia - With the presence } \\
\text { of foreign workers arriving in Indonesia, it is expected that } \\
\text { there will be an increase in investment in Indonesia. This is } \\
\text { also obtained from the results of the recruitment of foreign } \\
\text { workers. }\end{array}$ & \\
\hline 5 & $\begin{array}{l}\text { Triggering the productivity of the local workforce - } \\
\text { Competition of foreign and local workers will certainly } \\
\text { trigger the enthusiasm of local workers to continue to spur } \\
\text { themselves so they can survive in the competition }\end{array}$ & \\
\hline
\end{tabular}

Source: Scientific Rev (https://ilmugeografi.com/2020)

Based on table 2 above, it can be interpreted that there are 5 (five) positive impacts and 3 (three) negative impacts from foreign workers (TKA) in Indonesia. However, according to experts in Bachtiar and Fahmi (2011: 66) that the entry of foreign workers to economic growth, there is still debate among various experts 
(see for example Simon, 1988; Flores, 1997; Oscar, 1997; Osili; 2007) until the time These are as follows: (1) on the one hand, argues that the entry of foreign workers has a positive effect on economic growth, such as studies conducted by Dikson (1975) and Norman and Meikle (1985) in Australia; and (2) on the other hand argues that the entry of foreign workers has an unfavorable effect on economic growth, employment opportunities, and the level of wages for local workers (TKL), and this situation occurs when the education and quality of foreign workers are lower than TKL (Jodge and Mancurz, 1984).

According to Law No.39 of 1999 concerning Human Rights, it states that: "Every citizen or community group has the right to establish a political party, non-governmental organization, or other organization to participate in the running of government and state administration in line with the guidance of protection, enforcement and promotion of human rights in accordance with statutory provisions ". The goals of social organizations are adjusted to their specific characteristics which are further elaborated in their programs in order to achieve national goals (Article 3 of Government Regulation No. 18 of 1986 which is the Implementation of Law No. 8 of 1985 concerning Community Organizations).

In this sense, the role of NGOs is a counterweight to play an integral role in creating a sense of social equality, and finding practical solutions to the problems of foreign workers, and preventing migrant workers from avoiding and not committing illegal acts through efforts to raise awareness of human rights, and collective action in among migrant workers because they directly contribute to driving the progress of the companies where they work. NGOs are expected to be able to bridge the problems of foreign workers in line with the will of the community and the government, as well as reach the needs of the community more quickly as a preventive institution for foreign workers.

Thus, the role of NGOs / Cooperation Agencies is one of the government partners in carrying out development in various fields. According to Olena P. Maslyukivska in the Directorate of Socio-Cultural and International Organizations of Developing Countries, the Multilateral Directorate General of the Ministry of Foreign Affairs (2011: 2) states that the role of Non-Government Organizations (NGOs) / Cooperation Agencies is to design, study and work on programs and projects into six categories: (1) Development and operation of infrastructure; (2) Supporting innovation, demonstration and pilot projects; (3) Facilitating communications; (3) Technical assistance and training; (4) Research, monitoring and evaluation; ; and (5) Advocacy for and with the poor.

Then, the very strategic and very important role of Non Government Organizations (NGOs) is as a practical solution for foreign workers, and prevents migrant workers from avoiding and not committing illegal acts through efforts to increase awareness of human rights (HAM) as follows:

a. The role of mentoring for foreign workers from the educational preventive aspect is to conduct socialization related to the norms of using foreign workers to employers / sponsors with the aim of minimizing potential violations or criminal acts.

b. The role of mentoring for foreign workers from the non-justicia repressive aspect is to carry out examinations of violations of the use of foreign workers, either pro-actively or responsively based on reports from the public, covering administrative and technical aspects. Administrative aspects include administrative completeness, including: RPTKA, IMTA, SK for the Appointment of Associate TKI, DKP-TKA, Passport \& Limited Stay Permit (ITAS), Syllabus for Assistance Training, Realization Report of the Implementation of Education and Training, diplomas \& certificates of competence / work experience for foreign workers. While the technical aspects include the suitability between documents and implementation in the field, namely the IMTA position according to the job, the work location of the TKA, the validity period of the IMTA, the implementation of technology transfer, taking information from the TKA.

c. The role of mentoring for foreign workers from the repressive aspect of pro justicia includes investigations and investigations into violations of regulations on the use of foreign workers).

Thus, the role mechanism that can be carried out by Non-Government Organizations (NGOs) in an effort to protect and assist foreign workers in Indonesia is that NGOs play an integral role in creating a sense of social equality through education and training programs through the 4 (four) National Pillars of training programs, namely: Pancasila, UUD 1945, the Unitary State of the Republic of Indonesia (NKRI), and 
Bhinneka Tunggal Ika as well as certification to foreign workers includes the following materials: (1) An overview of ideology, politics, economy, social, culture, law and security for foreign workers in order to anticipate the impact of foreign workers in work activities and in life in Indonesian society; and (2) Fostering foreign workers in a continuous and sustainable manner, namely maintaining and enhancing good relations with all parties including the government and the wider community both in work and in activities outside of work so that foreign workers feel that they are and work like in their own home country.

\section{Conclusions and Suggestions}

Based on this research, it can be concluded that foreign workers (TKA) can be interpreted as a series of efforts to increase investment, transfer of technology and transfer skills to TKI, as well as expand job opportunities to accelerate economic growth by attracting investors to invest in Indonesia. However, it is necessary to guarantee the basic rights of workers / labor and guarantee equal opportunity and treatment without discrimination on any basis to realize the welfare of workers / laborers and their families while still paying attention to the laws and regulations that complement the smooth use of foreign workers (TKA) and labor local work (TKL) and taking into account the progress of the business world. Then, optimizing the involvement and active participation of NGOs is very important so it is highly recommended in the preventive educational aspect, the repressive aspect of non justicia, and the repressive aspect of the pro justicia. Because NGOs are strategic institutions and as practical solutions for foreign workers, and prevent migrant workers from avoiding and not committing illegal acts through efforts to increase awareness of human rights in Indonesia.

\section{References}

[1.] Al Faqir, Anisyah ; \& Moerti, Wisnoe. (2020). Poin-Poin Perubahan UU Ketenagakerjaan di Omnibus Law Cipta Kerja (II), 8 Oktober 2020 https://www.merdeka.com/peristiwa/poin-poinperubahan-uu-ketenagakerjaan-di-omnibus-law-cipta-kerja-ii.html

[2.] Artikel Hukum Bisnis dan Perbankan. TENAGA KERJA ASING DI INDONESIA: KEBIJAKAN DAN IMPLEMENTASI. http://ditjenpp.kemenkumham.go.id/hukum-bisnis/1427-tenaga-kerjaasing-di-indonesia-kebijakan-dan-implementasi.html

[3.] Banda, Nawarathna. (2019). Globalization and its Economic Social Political and Cultural impact. Researchgate Publication. https://www.researchgate.net/publication/330496428 _Globalization_and_its_Economic_Social_Political_and_Cultural_impact

[4.] Bhorat, Harroon; \& Lundall, Paul. (2004). Employment and Labour market effects of globalization: Select issues for policy management. Employment Strategy Papers. International Labour Office, Geneva. http://ilo.org/wcmsp5/groups/public/---ed_emp/--emp_elm/documents/publication/wcms_114330.pdf (Accesssed on November 10, 2020)

[5.] Babbie, Earl . (1986). The Practice of Social Research, fourth edition (California, Belmont: Wadsworth Publishing Co

[6.] Dewi, Dewa Ayu Putu Shandra. (2018). HARMONISASI PERATURAN PERUNDANGUNDANGAN TENTANG KETENAGAKERJAAN INDONESIA PASCARATIFIKASI KONVENSI INTERNASIONAL PEKERJA MIGRAN TAHUN 1990. REFORMASI ISSN 20887469 (Paper) ISSN 2407-6864 (Online) Volume $8 \quad$ Nomor 1 https://media.neliti.com/media/publications/319676-harmonisasi-peraturan-perundang-undangand2fc9977.pdf (Accesssed on November 9, 2020)

[7.] Direktorat Sosial Budaya dan Organisasi Internasional Negara Berkembang Direktorat Jenderal Multilateral Kementerian Luar Negeri. DIREKTORI ORGANISASI INTERNASIONAL NONPEMERINTAH (OINP) DI INDONESIA . Cetakan Pertama, Desember 2011 ISBN: 978-60219694-0-3.

[8.] Fitriah, Evi. (2019). Perlindungan Hukum Terhadap Tenaga Kerja Lokal (Analisis Yuridis Peraturan Presiden Nomor 20 Tahun 2018 Tentang Penggunaan Tenaga Kerja Asing) (Skripsi). Fakultas Syariah dan Hukum Universitas Islam Negeri Syarif Hidayatullah Jakarta. http://repository.uinjkt.ac.id/dspace/handle/123456789/49261

[9.] Guttal, Shalmali. (2007). Globalisation. Development in Practice. Taylor \& Francis, Ltd. Vol. 17, No. 4/5 (Aug., 2007), pp. 523-531: http://www.jstor.org/stable/25548249 
[10.] Hastuti, Hesty .(2005). LAPORAN AKHIR TIM PENELITIAN TENTANG PERMASALAHAN HUKUM TENAGA KERJA ASING DI INDONESIA. BADAN PEMBINAAN HUKUM NASIONAL DEPARTEMEN HUKUM DAN HAK ASASI MANUSIA REPUBLIK INDONESIA TAHUN

2005. https://bphn.go.id/data/documents/22Penelitian\%20TENAGA\%20KERJA\%20ASING.pdf

[11.] Jaumotte, Florence; and Tytell, Irina. (2007). How Has The Globalization of Labor Affected the Labor Share in Advanced Countries?. International Monetary Fund WP/07/298 IMF Working Paper Research Department December 2007

[12.] Jazuli, Ahmad . (2018). EKSISTENSI TENAGA KERJA ASING DI INDONESIA DALAM PERSPEKTIF HUKUM KEIMIGRASIAN (The Existence of Foreign Workers in Indonesia From The Immigration Law Perspective) Pusat Pengkajian dan Pengembangan Kebijakan Badan Penelitian dan Pengembangan Hukum dan HAM Kementerian Hukum dan HAM RI. https://core.ac.uk/download/pdf/268381342.pdf (Accesssed on November 9, 2020)

[13.] [Keputusan Presiden Nomor 75 Tahun 1995 Tentang Penggunaan Tenaga Kerja Warga Negara Asing Pendatang (TKWNAP)

[14.] Keputusan Presiden Nomor 75 Tahun 1995 Tentang Penggunaan Tenaga Kerja Warga Negara Asing Pendatang (TKWNAP)

[15.] Keputusan Menteri Kehakiman Republik Indonesia Nomor M.01.HT.04.02 Tahun 1997 Penggunaan Ahli Hukum Warga Negara Asing oleh Kantor Konsultan Hukum Indonesia

[16.] Keputusan Menteri Tenaga Kerja dan Transmigarasi Nomor 223 Tahun 2003 Tentang Jabatanjabatan di Lembaga Pendidikan yang Dikecualikan dari Kewajiban Membayar Kompensasi

[17.] Keputusan Direktur Jenderal. Penerbitan Keputusan Direktur Jenderal Nomor 3/7009/HK.08/VIII/2019 tentang Penyelenggaraan Program Asuransi bagi Tenaga Kerja Asing yang Bekerja Kurang dari Enam Bulan

[18.] Khoe, Fenny Natalia. (2013). Hak Pekerja Yang Sudah Bekerja Namun Belum Menandatangani Perjanjian Kerja Atas Upah Ditinjau Berdasarkan Undang-Undang Nomor 13 tahun 2003 tentang Ketenagakerjaan VOL 2 NO 1 (2013): CALYPTRA : JURNAL ILMIAH MAHASISWA UNIVERSITAS SURABAYA.. https://journal.ubaya.ac.id /index.php/jimus/article/view/135 (Accesssed on November 10, 2020)

[19.] Khulaidah, Nisrina Khansa'. (2019). STRATEGI INDONESIA DALAM MENGOPTIMALKANPEMANFAATAN KESEPAKATAN ASEAN ECONOMICCOMMUNITY (AEC) 2015 MENGENAI ALIRAN BEBASTENAGA KERJA TERAMPIL (Skilled Labor) di INDONESIA. FAKULTAS ILMU SOSIAL DAN ILMU POLITIK

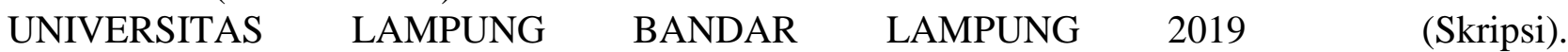
http://digilib.unila.ac.id/58324/3/3.\%20SKRIPSI\%20TANPA\%20BAB\%20PEMBAHASAN.pdf (Accesssed on November 11, 2020)

[20.] Masnun,Leolita; \& Wijayani, Erly. (2010). RATIFIKASI INTERNATIONAL CONVENTION ON THE PROTECTION OF THE RIGHTS OF ALL MIGRANT WORKERS AND MEMBERS OF THEIR FAMILIES DAN UPAYA PERLINDUNGAN TENAGA KERJA INDONESIA. Jurnal Masyarakat \& Budaya, Volume 12 No. 1 Tahun 2010. jmb.lipi.go.id (Accesssed on November 10, 2020)

[21.] Miru, Ahmadi. (2008). Hukum Kontrak dan Perancangan Kontrak. Jakarta: PT. Rajagrafindo Persada

[22.] Peraturan Menteri Hukum dan HAM RI Nomor M.09-Pr.07.10 Tahun 2007 Tentang Organisasi Dan Tata Kerja Departemen Hukum dan HAM RI

[23.] Peraturan Menteri Nomor PER.02/MEN/III/2008 Tentang Tata Cara Penggunaan Tenaga Kerja Asing

[24.] Peraturan Presiden Nomor 20 Tahun 2018 tentang Penggunaan Tenaga Kerja Asing

[25.] Peraturan Menteri Ketenagakerjaan Nomor 10 Tahun 2018 tentang Tata Cara Penggunaan Tenaga Kerja Asing

[26.] Pigai, Natalius.(2019). Menciptakan Lapangan Kerja, Mengentaskan Pengangguran. Senin, 18 November 2019. https://www.faktanews.id/2019/11/menciptakan-lapangan-kerja-mengentaskan.html (Accesssed on November 9, 2020) 
[27.] Pinangkaan, Nelly. (2015). MAKNA PASAL 33 UNDANG-UNDANG DASAR 1945 DALAM PEMBANGUNAN HUKUM EKONOMI INDONESIA. Lex Administratum, Vol. III/No. 5/Juli/2015. https://ejournal.unsrat.ac.id/index.php/administratum/article/view/18972/ 18531 (Accesssed on November 9, 2020)

[28.] Pottag, .Anis Tiana. (2018) POLITIK HUKUM PENGENDALIAN TENAGA KERJA ASING YANG BEKERJA DI INDONESIA Media Iuris Vol. 1 No. 2, Juni 2018 e-ISSN: 2621-5225 DOI: 10.20473/mi.v1i2.8827. file:///C:/Users/user/Downloads/8827-28803-2-PB.pdf (Accesssed on November 11, 2020)

[29.] Sandi, Ferry. (2020). Omnibus Law: Pekerja Asing Dipermudah Masuk RI! CNBC Indonesia 07 October 2020. https://www.cnbcindonesia.com/news/20201007135355-4-192504/omnibus-lawpekerja-asing-dipermudah-masuk-ri (Accesssed on November 10, 2020)

[30.] Scientific Rev: Redaksi Ilmugeografi. "8 Dampak Tenaga Kerja Asing di Indonesia: Positif dan Negatif". https://ilmugeografi.com/ilmu-sosial/dampak-tenaga-kerja-asing-di-indonesia (Accesssed on November 11, 2020)

[31.] Survei Tenaga Kerja Asing (TKA) tahun 2009 oleh Bank Indonesia. Biro Neraca Pembayaran Direktorat Statistik Ekonomi dan Moneter. file:///C:/Users/user/Downloads/92398eaf62dd4711b8b3bca8a3b5378bSurveiTKAIndonesia2.pdf . (Accesssed on November 11, 2020)

[32.] Undang-Undang Nomor 13 Tahun 2003 tentang Ketenagakerjaan.

[33.] Undang-Undang No. 11 Tahun 2020 tentang Cipta Kerja

[34.] Undang-Undang No.39 Tahun1999 tentang Hak Asasi Manusia

[35.] Undang-Undang Nomor 8 Tahun 1985 Tentang Organisasi Kemasyarakatan

[36.] UNCTAD-United Nations Conference on Trade and Development. (2008). GLOBALIZATION FOR DEVELOPMENT: THE INTERNATIONAL TRADE PERSPECTIVE. UNITED NATIONS New York and Geneva, 2008 https://unctad.org/system/files/official-document/ditc20071_en.pdf (Accesssed on November 9, 2020)

[37.] Wignjosoebroto, Soetandyo. (2002). Hukum: Paradigma, Metode dan Dinamikanya, Jakarta: ELSAM \& HUMA

[38.] Zamroni.(2003). Optimalisasi manfaat ekonomi dari globalisasi, Pusat Penelitian Ekonomi, Lembaga Ilmu Pengetahuan Indonesia, Jakarta

[39.] Zhenmin, Liu. (2020). Recovering better: economic and social challenges and opportunities A compilation of the High-level Advisory Board on Economic and Social Affairs Published by the United Nations, Department of Economic and Social Affairs New York, New York 10017, United States of America Copyright (C) 2020 United Nations. https://www.un.org/development/desa/en/wp-content/uploads/2020/07/RECOVER__BETTER_ 0722-1.pdf (Accesssed on November 9, 2020) 